\title{
Šola in medvrstniško nasilje v Sloveniji: raziskovalni pristopi, metode in metaanaliza dosedanjega raziskovanja v Sloveniji
}

\author{
Ajda Šulc in Aleš Bučar Ručman
}

\begin{abstract}
Š ola je ključna družbena institucija sistematičnega izobraževanja in hkrati tudi vzgoje. Na njeno osrednjo vlogo kaže Althusserjev (2000) zaključek, da je šola eden ključnih ideoloških aparatov države in največja pridobitev francoske revolucije, ki je prenesla izobraževanje izpod avtoritete cerkve pod okrilje sekulariziranega državnega sistema. Šola je institucija, ki otroku poleg družine v dokaj zgodnjem otroštvu in relativno dolgotrajnem obdobju preko množice interakcij z vrstniki, učitelji in drugimi strokovnimi delavci prenaša, uči in tudi sooblikuje vrednote ter norme. Vendar ne smemo spregledati, da šolsko okolje ni izolirano in ločeno od širše družbe. Ravno obratno, šola - tako v kontekstu delovanja formalnega izobraževalnega in vzgojnega sistema kot mesto vzpostavljanja neformalnih interakcij - je preslikava najprej neposrednega lokalnega in nato širšega družbenega okolja. V šoli se kažejo vse njegove prednosti, odlike, priložnosti kot tudi slabosti, grožnje in težave. Ena takšnih težav je tudi nasilje $\mathrm{v}$ šolskem prostoru.

Kot nazorno pokaže Henry (2000), je pomembno razumevanje, da povezava med nasiljem in šolo poteka na številnih nivojih in vključuje tako medosebno nasilje, katerega akterji so učenci, kot tudi nasilje učiteljev, vodstev šol, staršev, lokalne in državne oblasti - med seboj in nad učenci, škodljive družbene procese in prakse, ki se kažejo kot institucionalizirane oblike rasizma, seksizma in drugih oblik diskriminacije. Lešnik Mugnaioni, Koren, Logaj in Brejc (2009) nasilje v šolskem okolju delijo glede na udeležence, in sicer na nasilje med učenci, učencev nad učitelji, učiteljev nad učenci, med zaposlenimi ter med starši in učitelji, kar pa se lahko izvaja na različne načine, ki jih bomo klasificirali v nadaljevanju.
\end{abstract}


Pomembni značilnosti za razumevanje vzrokov in posledic nasilja sta intenziteta in pogostost nasilnih dejanj. Slednja igra pomembno vlogo pri posebni obliki nasilja v šolah, na katero se bomo osredotočili v nadaljevanju, tj. pri medvrstniškem nasilju.

\section{Medvrstniško trpinčenje, nadlegovanje, ustrahovanje, nasilje}

Znanstveni diskurz $\mathrm{v}$ angleškem jeziku uporablja termin bullying kot označevalec, ki vključuje različne oblike medvstniškega nasilja. Enotnega prevoda tega termina $\mathrm{v}$ slovenščini ne poznamo. $\mathrm{V}$ zadnjih desetletjih je mogoče pri nas zaslediti uporabo različnih izrazov, med katerimi so $\mathrm{v}$ ospredju medvrstniško trpinčenje, nadlegovanje, ustrahovanje, preganjanje (Bučar Ručman, 2004; Dekleva, 1997; 200I; Pušnik, 2012), zlorabljanje, tiraniziranje ali (med)vrstniško nasilje (Dekleva, 20or; Lešnik Mugnaioni in drugi, 2009; Marjanovič Umek in drugi, 2004). ${ }^{\mathrm{I}}$ Podobno pestrost in razpršenost je mogoče zaznati pri definicijah omenjenih dejanj oz. procesov. Kljub različnim pristopom in pogledom na medvrstniško nasilje lahko prepoznamo pri avtorjih naslednje skupne imenovalce:

I) gre za ponavljajoče se nasilje nad otrokom ali mladostnikom, ki lahko nastopa $\mathrm{v}$ različnih oblikah in intenziteti;

2) izvršujejo ga njegovi vrstniki oz. drugi mladostniki (eden ali več);

3) največkrat se dogaja $\mathrm{v}$ šoli ali v povezavi z njo;

4) traja daljše časovno obdobje; in

5) povzroča strah, neprijetne občutke in trpljenje (Bučar Ručman, 2004; Dekleva, 200I; Lebar, Nagode in Žerjav, 2017; Lešnik Mugnaioni in drugi, 2009; Marjanovič Umek in drugi, 2004; Pušnik, 2012).

Večina avtorjev pri tem dodaja, da so storilci nesorazmerno močnejši od žrtve, ki se težko ali sploh ne more braniti sama (Lešnik Mugnaioni in drugi, 2009; Olweus, 2009; Pušnik, 2012).

Med različnimi oblikami medvrstniškega nasilja je bilo v preteklosti $\mathrm{v}$ ospredje postavljeno zgolj fizično in besedno nasilje (Craig, 1998), s poglobljenim naslavljanjem problema pa avtorji danes $\mathrm{v}$ definicijo vključujejo tudi druge oblike nasilja z zgoraj opisanimi značilnostmi. Kljub temu, da pogosto uporabljajo neenotne klasifikacije ali zgolj naštevajo pojavne oblike, lahko zaključimo, da je med oblike medvrstniškega nasilja vključeno fizično (uporaba fizične sile), verbalno (besede, ki žrtev prizadenejo),

I V nadaljevanju prispevka uporabljamo termin medvrstniško nasilje kot splošen označevalec za različne oblike medvrstniškega trpinčenja, nadlegovanja, ustrahovanja, preganjanja in druge oblike dejanj vrstnikov, ki oškodujejo žrtve. 
psihično, socialno ali odnosno (socialno izločanje in manipulacije), ekonomsko (vključuje materialno oškodovanje žrtve in/ali pridobitev koristi za storilca), kibernetsko (uporaba informacijsko komunikacijske tehnologije) in spolno nasilje (Boske in Osanloo, 2015; Bučar Ručman, 2004; Lešnik Mugnaioni in drugi, 2009; Posinc in Košir, 2016; Pušnik, 2012). Različne oblike nasilja so lahko očitne in lažje prepoznane, medtem ko so druge bolj subtilne, posredne, vendar nič manj škodljive za žrtve. Negativne posledice, ki so lahko dolgotrajne in tudi skrajne, so vzrok, da se tem pojavom namenja veliko pozornosti ter prizadeva za prepoznavanje, zaznavanje, preprečevanje in pomoč žrtvam medvrstniškega nasilja. Pred skoraj dvema desetletjema je Dekleva (20or) zapisal, da je eno prvih razprav o medvrstniškem nasilju v slovenskem prostoru spremljalo presenečenje ob problematiziranju tega pojava, ki se ga je takrat razumelo kot normalnega, vsakodnevnega in celo sprejemljivega. Takrat so bile razmere drugačne, upamo pa si trditi, da se je stanje - vsaj, kar zadeva preprečevanje, ozaveščanje in ukrepanje (ne pa tudi raziskovanje tega pojava) kasneje še dodatno izboljšalo. Tako se danes (še) bolj zavedamo posledic takšnega ravnanja. To se kaže v številnih programih in aktivnostih za odkrivanje in preprečevanje medvrstniškega nasilja, v eksplicitnem zapisu te oblike nasilja v Resoluciji o nacionalnem programu preprečevanja in zatiranja kriminalitete za obdobje 2019-2023 (v času pisanja prispevka je bilo besedilo resolucije sprejeto na Vladi RS in poslano v obravnavo v Državni zbor RS). Ravno zavedanje skrajnih in obsežnih posledic medvrstniškega nasilja ter želja po prevenciji sta vodila slovensko policijo in Ministrstvo za izobraževanje, znanost in šport, da so skupaj z Evropsko komisijo v sklopu programa Structural Reform Support Service (SRSS) pričeli izvajati projekt Preventing bullying and reducing violence among minors in Slovenia (2018-2020). ${ }^{2}$

Medvrstniško nasilje v prvi vrsti in najbolj neposredno prizadene žrtve. Poleg neposredno zadanih fizičnih poškodb prihaja do psihičnih, psihosocialnih in psihosomatskih težav, depresije, nižje samopodobe, posledično težjega vključevanja $\mathrm{v}$ družbo in težav $\mathrm{v}$ posameznikovem osebnem razvoju in nadaljnjem življenju (Bučar Ručman in drugi, 2004; Cvek in Pšunder, 2013; Cross, Lester in Barnes, 2015; Graham, 2016; Moore in drugi, 2017; Pušnik, 2012; Smith, 2016). Poleg otrok, ki so že zaradi osebnostne in fizične šibkosti bolj nagnjeni k viktimizaciji (Lešnik Mugnaioni in drugi, 2009), so žrtve medvrstniškega nasilja praviloma »drugačni«, socialno izključeni zaradi lastnosti, ki so same po sebi trivialne in predstavljajo zgolj odstopanje od večinske skupine otrok (npr. način oblačenja,

2 Oba avtorja tega prispevka sodelujeta pri izvajanju tega projekta. 
izgled, narečje) (Thornberg, 20II). Pogosteje se z različnimi oblikami medvrstniškega nasilja srečujejo pripadniki LGBT (lezbijke, geji, biseksualne in transspolne osebe) populacije (Boske, 20I5; Maljevac in Magic, 2009), priseljenci in njihovi potomci (Bučar Ručman, 20I4; Razpotnik, 2006), otroci etničnih, »rasnih « in verskih manjšin, učenci z učnimi težavami (Boske, 20I5; Sullivan, 20II) in otroci z invalidnostjo (Twyman in drugi, 20Io). Ob tem ne gre spregledati, da neposredne žrtve medvrstniškega nasilja niso edini oškodovanci. Sullivan (20II) v njih prepoznava zgolj prvo od petih skupin žrtev. Ugotavlja, da so sekundarne žrtve družinski člani primarnih žrtev, ki ob viktimizaciji ljubljenega otroka občutijo žalost, empatijo in jezo. Tretjo skupino predstavljajo priče, večinoma drugi otroci in vrstniki z občutki strahu ali celo krivde, da nasilja niso ustavili, ali pa jih takšna odklonskost celo pritegne. Medvrstniško nasilje prinaša podobne posledice na neposredno okolje (npr. celotno šolo), na zadnji stopnji pa celo na (naj)širšo skupnost. Pogosto je spregledano, da je izvajanje medvrstniškega nasilja povezano tudi z negativnimi posledicama pri nasilnežu, saj pri njih obstaja večja verjetnost, da bodo tudi kasneje v življenju izvajali delikventna in kriminalna dejanja (Lebar in drugi, 20ı6; Pušnik, 20I2). Medvrstniško nasilje ustvarja spiralo nezaželenih ravnanj in posledic, ki tako žrtev kot tudi storilca zaznamujejo pri nadaljnjih socialnih stikih. Pri žrtvah to ne pomeni zgolj poglabljanja viktimizacije, ampak lahko vodi tudi v izvajanje nasilja nad šibkejšimi in prevzemanje vloge nasilnež - žrtev (Boske in Osanloo, 20I; Craig in drugi, 2009). Hkrati lahko na drugi strani izvajanje nasilja povečuje možnosti za viktimizacijo. Patchin in Hinduja (2008) namreč ugotavljata, da obstaja bistveno večja verjetnost viktimizacije akterjev t. i. tradicionalnega nasilja preko kibernetskega nasilja. ${ }^{3}$

Razvoj in množična uporaba informacijsko-komunikacijske tehnologije sta vzpostavila novo platformo za izvajanje medvrstniškega nasilja in ga razširila izven časovnih ter prostorskih omejitev t. i. tradicionalnega oziroma »klasičnega « nasilja v šolah in drugih fizičnih prostorih, kjer prihaja do interakcije med otroci oziroma mladostniki. Pojavi se oblika medvrstniškega nasilja, pri katerem fizična in socialna moč nista pomembni, žrtev pa se pred njim ne more skriti oziroma se mu umakniti. Kibernetsko medvrstniško nasilje (angl. cyberbullying) lahko najširše opredelimo kot

Različni avtorji (npr. Netzley, 20I4; Patchin in Hinduja, 2008; Riebel, Jager in Fischer, 2009) ugotavljajo, da je večina otrok in mladostnikov udeleženih $v$ kibernetskem medvrstniškem nasilju, vključena tudi v tradicionalne oziroma klasične oblike nasilja v šoli. Najpogosteje nastopajo $v$ isti vlogi (žrtev ali storilec), v nekaterih primerih pa prevzemajo druge vloge. 
nasilje preko interneta ali digitalne komunikacije (Parks, 2013). ${ }^{4}$ Večina avtorjev pri oblikovanju definicije kibernetskega medvrstniškega nasilja izhaja iz predhodno opisanih značilnosti klasičnega medvrstniškega nasilja. Opredeljujejo ga kot ponavljajoče in namerno nasilje, ki ga daljše časovno obdobje izvajajo vrstniki žrtve, ki občuti strah in se sama težko brani, nasilje pa se izvaja z uporabo digitalnega komuniciranja (Riebel, Jager in Fischer, 2009; Weber in Pelfrey, 2014; Završnik, 2013; Završnik in Sedej, 2or2). Obsega žalitve, grožnje, izsiljevanje, širjenje laži ali poniževanje preko e-pošte, sistemov za takojšnje sporočanje, klepetalnic, komentarjev ali objav na družbenih omrežjih, ustvarjanja lažnih profilov in podobno (Lebar in drugi, 2017; Parks, 2013). Namen teh dejanj je prizadeti, ponižati, ustrahovati, manipulirati ali socialno izključiti žrtev oziroma ji uničiti njene odnose z vrstniki (Netzley, 20I4; Sullivan, 20II). Pri tem podobno kot pri klasičnem oz. tradicionalnem nasilju (Bučar Ručman, 2004) medsebojna agresija oseb, ki se v to podajo zavestno, prostovoljno in s približno enakovredno porazdelitvijo moči, ni klasificirana kot kibernetsko medvrstniško nasilje (Sullivan, 20II).

\section{Prepoznavanje in raziskovanje medvrstniškega nasilja}

Za razumevanje družbenega dogajanja in medsebojnih odnosov, odpravljanje vzrokov negativnih pojavov in uspešno soočanje s posledicami, načrtovanje in oblikovanje učinkovitih ukrepov za pomoč vsem žrtvam sta ključnega pomena znanstveno raziskovanje in uporaba zanesljivih, veljavnih in natančnih raziskovalnih metod. To velja tudi za razumevanje in ukrepanje na področju medvrstniškega nasilja. Kot pravi Pušnikova (20I2), ga moramo znati prepoznati, nanj reagirati in ozaveščati potencialno vpletene. Natančna analiza stanja je prvi korak pri načrtovanju preventivnih aktivnosti. $V$ to analizo je treba zajeti prepoznavanje pojavnih oblik, obseg in specifične značilnosti medvrstniškega nasilja. Ugotoviti moramo, kako pogosto se otroci in mladostniki srečujejo z medvrstniškim nasiljem, v kakšnih oblikah in kje, kakšni so razlogi za takšno vedenje in kakšno pomoč iščejo, dobijo ali pogrešajo žrtve in priče (Bučar Ručman, 2009). Šele na podlagi teh informacij in njihove umestitve v širši družbeni kontekst lahko razumemo medvrstniško nasilje in nato oblikujemo preventivne ukrepe in strategije.

Raziskovanje nam omogoča tudi vpogled v »sivo polje « medvrstniškega nasilja, tj. vpogled v drugače neprijavljene ali nezaznane primere.

4 Nekateri avtorji (npr. Weber in Pelfrey, 20I4) zagovarjajo razumevanje kibernetskega medvrstniškega nasilja kot posebne oblike, medtem ko ga drugi (npr. Netzley, 2014) prepoznavajo kot obliko medvrstniškega nasilja, pri kateri pride do prenosa trpinčenja iz šole in neposrednega fizičnega prostora $\mathrm{v}$ kibernetski prostor. 
Podatki različnih raziskav (npr. Bučar Ručman, 2004; Lobe in Muha, 20ı0; Posinc in Košir, 2016; Pušnik, 1999) kažejo, da učitelji podcenjujejo resnost in pogostost posameznih oblik nasilja $\mathrm{v}$ njihovih šolah v primerjavi z doživljanjem in zaznavami učencev. $Z$ raziskovanjem lahko ugotovimo, zakaj in na katerih področjih prihaja do odstopanj ter kateri so opozorilni znaki, ki jih kažejo učenci in dijaki ob doživljanju medvrstniškega nasilja. Na podlagi tega lahko ciljno izobrazimo pedagoške delavce in jih usposobimo, da bodo v prihodnosti takšna deviantna ravnanja zaznavali samostojno in se znali odzvati nanje (Pušnik, 2012). Še več, raziskovanje ima tudi ključno vlogo pri ocenjevanju uspešnosti izvedenih preventivnih aktivnosti (Bovaird, 2010), kar je pomembno pri načrtovanju preventivnih programov, saj želimo priporočiti in implementirati tiste, ki so se izkazali za učinkovite, oziroma ugotoviti, kaj obstoječi programi in aktivnosti ne naslavljajo. Raziskovanje medvrstniškega nasilja je torej ključnega pomena za vzgojne in izobraževalne delavce ter oblikovalce politik, ki naslavljajo ta problem (Ttofi in Farington, 2009: 13) - ob upoštevanju vseh negativnih posledic tega pojava pa lahko dodamo, da je ključnega pomena za celotno družbo.

\section{Opis raziskovalne metode}

Pri raziskovanju medvrstniškega nasilja se srečujemo s številnimi in večplastnimi izzivi. Pojav je med avtorji različno razumljen, pomembno vlogo pri njegovi zaznavi ima družbeni oziroma kulturni kontekst, vse to pa oteži mednarodne primerjave in postavlja pod vprašaj prenos in preprosto ponavljanje pristopov v različnih državah. Posinc in Košir (2016) zaključujeta, da se podatki raziskav o razširjenosti medvrstniškega nasilja razlikujejo zaradi različno postavljenih vprašanj, neenotne definicije in različnih načinov izbora enot v vzorec. Podroben pregled literature in raziskav pri nas potrdi te zaključke. Avtorji si niso enotni pri uporabi termina za označevanje medvrstniškega nasilja, v redkih empiričnih raziskavah pa je vprašljiva tudi konsistentnost operativnih definicij merjenega konstrukta, saj avtorji upoštevajo različne razsežnosti le-tega in zato pri raziskovanju ne vključujejo istih indikatorjev.

Osrednji namen pričujočega prispevka je prikazati ugotovitve različnih raziskav o medvrstniškem nasilju v Sloveniji in s pomočjo metaanalize ugotoviti, kakšna je skupna izmerjena pojavnost medvrstniškega nasilja $v$ Sloveniji. Osredotočili smo se na odkrivanje, kako konsistentno so izvedene

Metaanalize programov za zmanjševanje medvrstniškega nasilja potrjujejo, da so mladostniki, ki so se udeležili takšnih programov, občutno redkeje ocenili, da so žrtve medvrstniškega nasilja ali da le-tega izvajajo, kot njihovi vrstniki, kiv programe niso bili vključeni (več glej v Gaffney, Ttofi in Farrington, 2018; Ttofi in Farrington, 2009). 
Tabela ı: Pregled raziskav medvrstniškega nasilja v Sloveniji ı99ı-20ı8.

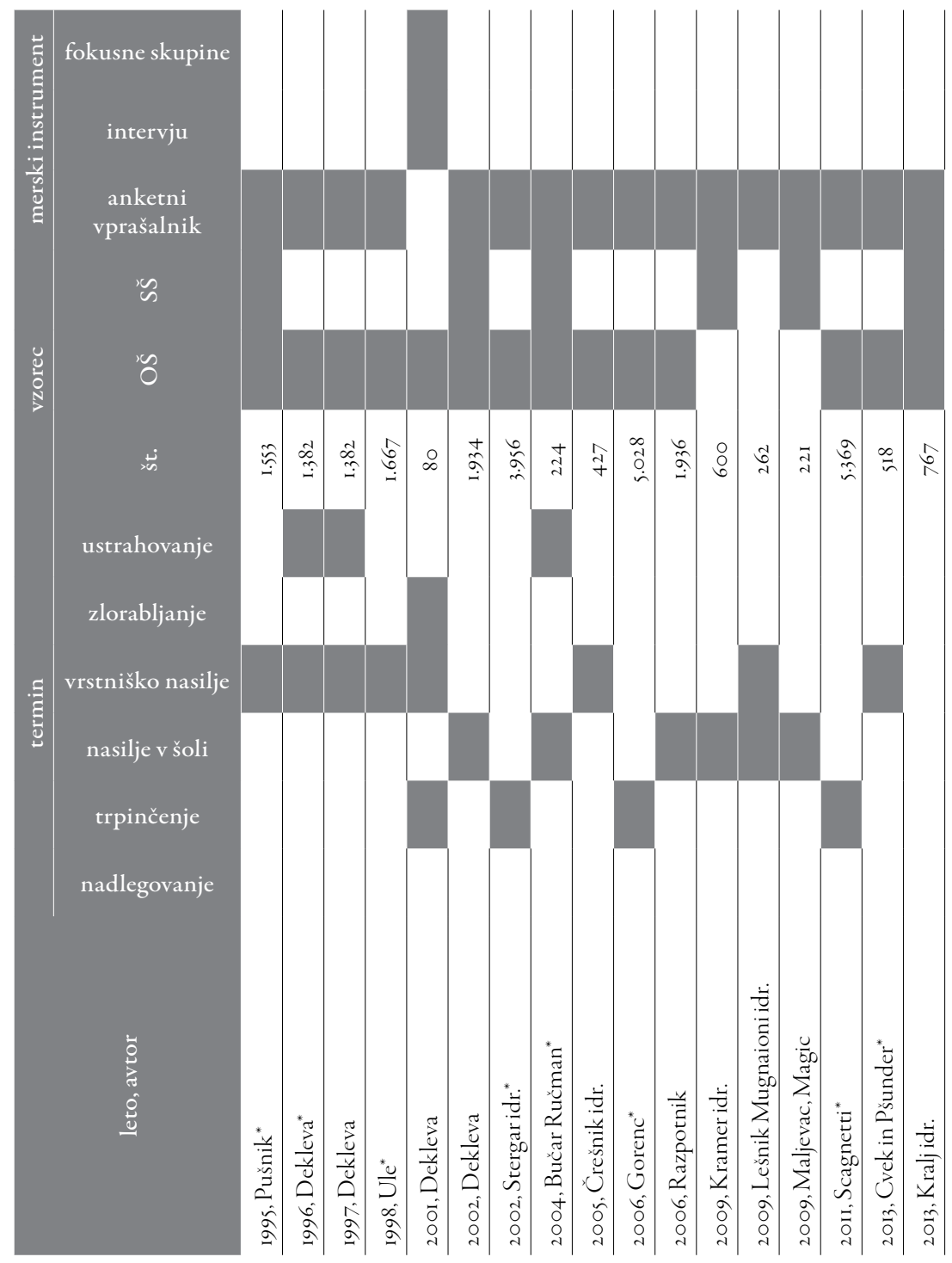




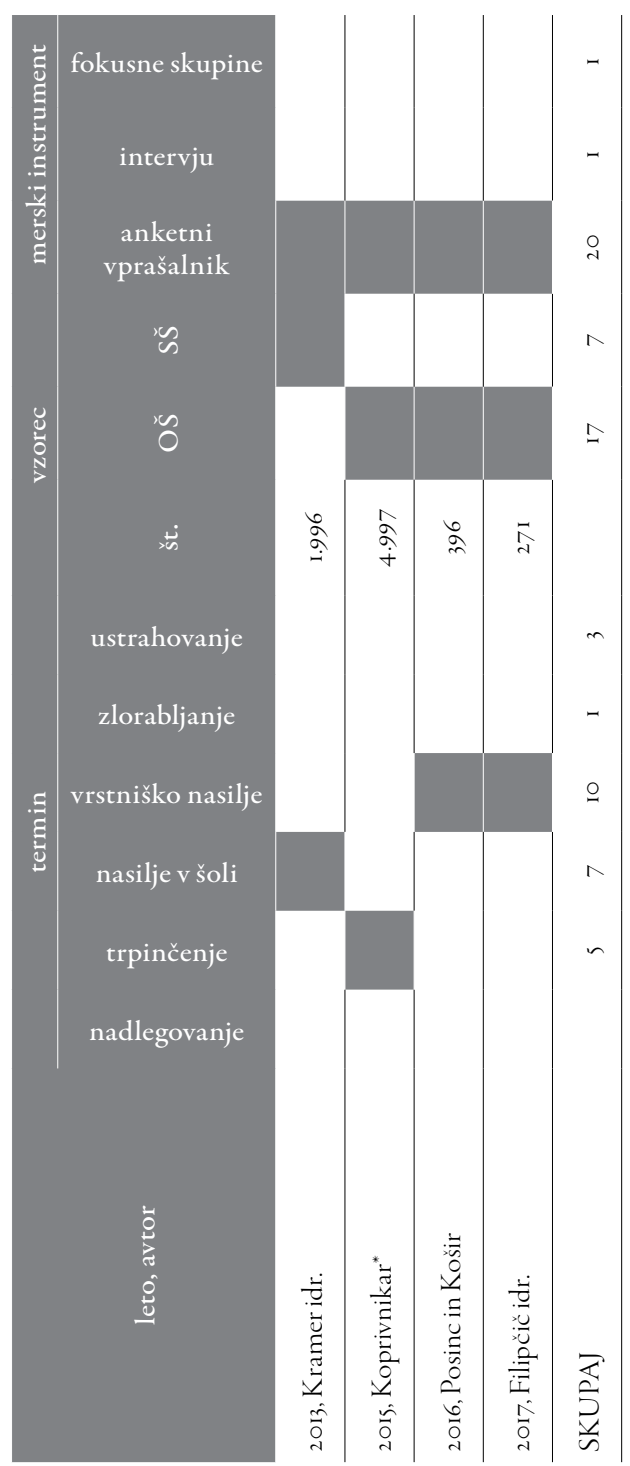

*Raziskava, vključena v metaanalizo.

raziskave in predstavljeni rezultati. S pomočjo baze podatkov Cobiss, iskalnikov Google in Google Scholar ter z uporabo pristopa »snežne kepe« smo na temo medvrstniškega nasilja našli i 7 I prispevkov. ${ }^{6}$ Med najdenimi

6 V bazah smo iskali s pomočjo I) ključnih besed: trpinčenje, ustrahovanje, nasilje všoli, mladoletniško nasilje, mladostniško nasilje, medvrstniško nasilje, mladoletniška delinkvenca, kibernetsko nasilje, kibernetsko nadlegovanje, cyberbullying, spletno nasilje, spletno na- 
prispevki jih je $25 \mathrm{~s}$ primarno empirično raziskavo, $\mathrm{v}$ podrobno analizo pa smo vključili 20 prispevkov (glej tabelo I). ${ }^{7}$ Od teh je 19 prispevkov merilo medvrstniško nasilje z uporabo kvantitativnih metod (anketni vprašalnik), le ena raziskava pa je uporabila kvalitativni metodi (intervju in fokusno skupino). V I6 raziskavah je bil vzorec sestavljen iz učencev osnovnih šol, v 6 iz dijakov srednjih šol, $\mathrm{v} 3$ primerih je bila raziskava izpeljana $\mathrm{v}$ osnovni in srednji šoli. Večinoma so $\mathrm{v}$ raziskavah merili pogostost pojavnosti medvrstniškega nasilja. Otroke in mladostnike so spraševali po viktimizaciji in storilstvu, občutno manj po opažanju nasilja tretjih oseb. Dve raziskavi (Lešnik Mugnaioni in drugi, 2009; Posinc in Košir, 2016) sta bili osredotočeni na pedagoške delavce in njihove zaznave nasilja v šolah. Redke raziskave so iskale korelacije med storilstvom oziroma viktimizacijo in dejavniki, kot so etnična pripadnost (Kralj, Žakelj in Rameša, 2013; Razpotnik, 2006), pripadnost LGBT (Maljevac in Magic, 2009) in osebnostne značilnosti (Dekleva, 1997). Primarni termini, ki so jih avtorji uporabljali pri raziskovanju, si po pogostosti uporabe sledijo: $\gg(\mathrm{med})$ vrstniško nasilje «, »nasilje v šoli«, »trpinčenje «, »ustrahovanje « in $\gg$ zlorabljanje«. Prispevki v veliki večini raziskovalnih metod ne opisujejo dovolj natančno, da bi lahko analizirali in primerjali načine postavljanja vprašanj in kako je bil izprašancem predstavljen ter definiran sam konstrukt medvrstniškega nasilja, o katerem so jih spraševali.

Manj pozornosti je bilo pri raziskovanju v Sloveniji posvečene kibernetskemu medvrstniškemu nasilju. Tako smo uspeli najti le štiri empirične raziskave ( $\mathrm{z}$ anketnimi vprašalniki), katerih rezultati iz več vidikov med seboj niso primerljivi. Završnik in Sedej (20I2) s svojo raziskavo izstopata že pri oblikovanju vzorca, saj sta anketirala odrasle (polnoletne) osebe. Na podobno težavo naletimo pri raziskavi Jontesa, Lutharja in Črniča (20I4), ki so v anketo vključili osebe I5-30 let starosti. Zgolj dve med seboj zelo podobni raziskavi sta se osredotočili na otroke in mladostnike (Lobe in Muha, 20I0; 20II). Raziskave se precej razlikujejo tudi po definiciji in razumevanju kibernetskega nasilja, po katerem sprašujejo anketirance. Vprašanja so postavljena zelo različno. Završnik in Sedej (20I2) sicer definirata kibernetsko nadlegovanje in sprašujeta po izkušnjah z njim,

dlegovanje, internetno nasilje, internet in nasilje, internetno nadlegovanje, mobilni telefoni in nasilje, mobilno nadlegovanje (da smo zajeli vse izpeljanke in besedne zveze, smo si pomagali z iskanjem po korenu besede in *); 2) avtorjev, pri čemer smo preverjali sledeče priimke avtorjev, ki so v našem prostoru poznani po raziskovanju različnih oblik nasilja: Antić Gaber, Areh, Bertok, Bučar Ručman, Dekleva, Filipčič, Marjanovič Umek, Meško, Muršič, Pavlović, Pušnik, Razpotnik, Tomori, Umek, Završnik.

7 Štiri prispevke smo izločili iz analize, ker niso merili medvrstniškega nasilja, temveč agresijo ali splošno odklonskost, do ene potencialno relevantne raziskave pa nismo uspeli dobiti dostopa. 
medtem ko ostali raziskovalci sprašujejo bolj po konkretnih primerih viktimizacije in zaznavanja, na primer po prejemanju »žaljivih sporočil na internetu«, »grožnjah«, »žaljivih SMS «, ustvarjanju »lažnega profila« in podobno.

\section{Metaanaliza pojavnosti medvrstniškega nasilja v Sloveniji}

\section{Kriteriji za vključitev raziskav v metaanalizo}

Vse raziskave o medvrstniškem nasilju smo podrobno pregledali in določili kriterije za vključitev raziskave $\mathrm{v}$ metaanalizo $\gg$ klasičnega $\ll$ oz. $\gg$ tradicionalnega « medvrstniškega nasilja. ${ }^{8} \mathrm{Z}$ uporabo te metode smo iskali odgovore na naša raziskovalna vprašanja o pojavnosti medvrstniškega nasilja pri nas in konsistentnosti izvedenih raziskav. Kriteriji za vključitev raziskave v metaanalizo so bili:

- $\quad$ raziskava je bila opravljena v Sloveniji in objavljena po letu 199I, do vključno maj 2019,

- uporaba kvantitativnih metod primarnega zbiranja podatkov, natančneje $\mathrm{z}$ anketo (izključili smo prispevke, ki so analizirali sekundarne statistične podatke in ki so podatke zbirali kvalitativno),

- $\quad$ vprašani so učenci in dijaki (ne učitelji ali starši), o kateremkoli načinu zaznavanja medvrstniškega nasilja (kot žrtve, storilci ali priče),

- podatki so podani v obliki števila in/ali deleža vprašanih z izkušnjami medvrstniškega nasilja na splošno (ne zgolj katere od oblik tega), specificirano, za katero obliko izkušenj gre,

- raziskava se je ukvarjala izključno ali (vsaj) primarno z medvrstniškim nasiljem (nismo vključili raziskav, ki so medvrstniško nasilje zajele le v nekaj vprašanjih, dodanih drugim širšim sklopom),

- dostopnost raziskave oziroma ugotovitev.

Ustreznih raziskav, ki so zadostovale vsem kriterijem za vključitev v metaanalizo, je bilo devet in so označene $\mathrm{v}$ Tabeli $\mathrm{I}$ in podrobneje prikazane v Tabeli 2.

\section{Kodiranje podatkov}

Podatke iz zbranih raziskav je kodirala prva avtorica prispevka in pri tem izpisala relevantne podatke $\mathrm{v}$ excelovo datoteko: avtorja/-e, leto izdaje, leto raziskave, vrsto raziskave (viktimizacijska, samoprijavitvena ali raziskava o zaznavanju nasilja tretjih oseb), velikost vzorca in deleže ugotovljenih izkušenj z medvrstniškim nasiljem po skupinah (spol, starost/razred,

8 Raziskav o spletnem medvrstniškem nasilju nismo vključili v metaanalizo, saj se med seboj (in od raziskav klasičnega medvrstniškega nasilja) metodološko in vsebinsko preveč razlikujejo in rezultati niso primerljivi. 
pogostost). Kjer so bili podatki dostopni, so bili izpisani tudi deleži in/ali število vključenih po posameznih skupinah (delež moških in žensk, deleži po starosti).

\section{Metaanaliza}

$\mathrm{Z}$ uporabo metaanalize smo analizirali vse raziskave medvrstniškega nasilja v Sloveniji, ki so merile isto spremenljivko (zaznavanje medvrstniškega nasilja med mladostniki) in iz katerih smo te vrednosti lahko pridobili v ustrezni obliki. Podatke smo analizirali s programom Comprehensive Meta Analysis $V_{3}$, ki nudi funkcijo avtomatskega izračuna velikosti učinkov za nadaljnje analize. Zaradi majhnega števila raziskav, ki so ustrezale pogojem, je bil izbor popolnoma ustreznih spremenljivk omejen, podatki pa zbrani v dokaj raznolikih oblikah. Že v izhodišču smo ločili podatke o zaznavanju medvrstniškega nasilja brez pogoja ponavljanja (vsaj enkrat) in ponavljajočega (v vprašanju označeno $\mathrm{z}$ »vsaj kdaj pa kdaj《, »vsaj občasno $\ll$ in podobno) in jih analizirali ločeno.

\section{Delež zaznanega medvrstniškega nasilja (vsaj enkrat)}

Raziskav, ki so merile zaznano medvrstniško nasilje na splošno in to predstavile v deležih, je bilo zgolj sedem, vendar so nekatere od njih merile več dimenzij zaznavanja (samoprijavitev, viktimizacija ali opažanje nasilja) in $s$ tem povečale število vrednosti, razpoložljivih za analizo. Ker predpostavljamo, da so zajete raziskave le slučajni del celotne slike populacije, z raznolikimi merskimi instrumenti in vzorci, smo za metaanalizo uporabili model slučajnih učinkov (Kastrin, 2008), s katerim se ob predpostavki heterogenosti raziskav izognemo preozkemu definiranju intervalov zaupanja in $s$ tem precenjevanju točnosti rezultatov (Hunter in Schmidt, 2004).

V Tabeli 2 in Grafu I so prikazane ocene velikosti učinkov posameznih raziskav in njihovi $95 \%$ intervali zaupanja. Velikosti kvadratov v grafu so sorazmerne z utežjo, dodeljeno posamezni raziskavi na podlagi velikosti vzorca. Opazimo lahko odstopanje vrednosti pri raziskavi Dekleve (1996), predvsem za vrednosti o zaznavanju opaženega nasilja. Odstopanja so razvidna tudi pri raziskavi, ki sta jo opravili Cvek in Pšunder (2013). Skupna ocena velikosti učinka znaša 33,3\% (95 \% interval zaupanja: 26,3 $\%$ do 4I,3 \%) zaznanega medvrstniškega nasilja. Izračun statistične heterogenosti ( $\mathrm{I}^{2}=99,5 \mathrm{I} \%$; $\mathrm{Q}=\mathrm{I524}$.34 I, $\left.\mathrm{df}(\mathrm{Q})=9\right)$ pokaže, da je ta izredno visoka ( $\mathrm{I}^{2}$ nad 70 \% (Rodseth in Marais, 2016)), kar kaže na vsebinske razlike med študijami in potrjuje ustreznost uporabe modela slučajnih učinkov za metaanalizo. Na podlagi tega smo $\mathrm{v}$ nadaljevanju izvedli analizo pristranskosti v objavljanju in analize podskupin, da bi ugotovili potencialne razloge za vzorčno in metodološko heterogenost (Kastrin, 2008). 
Tabela 2: Rezultati metaanalize za vse vrednosti raziskav glede na vrsto študije, vključene v analizo.

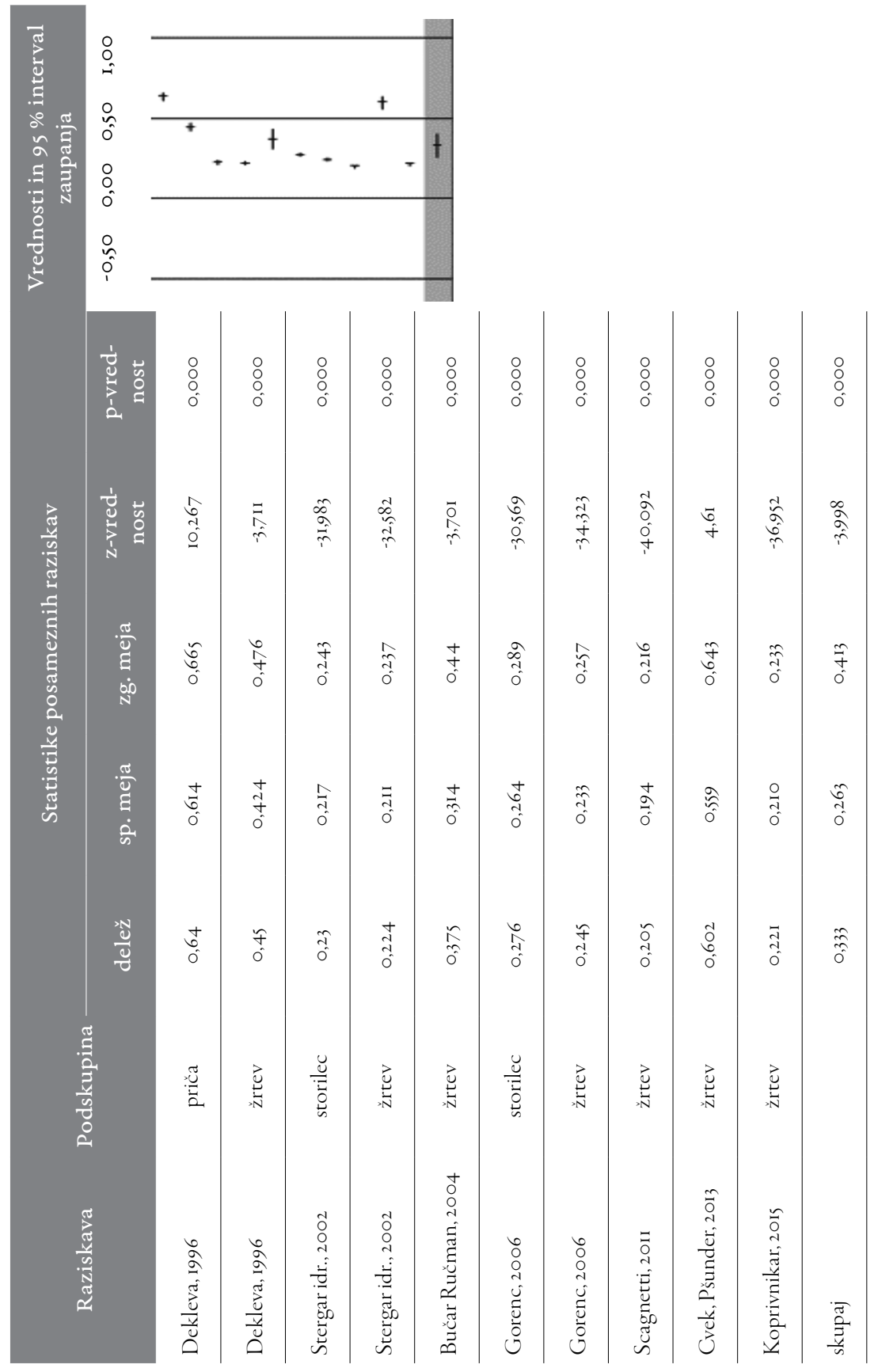




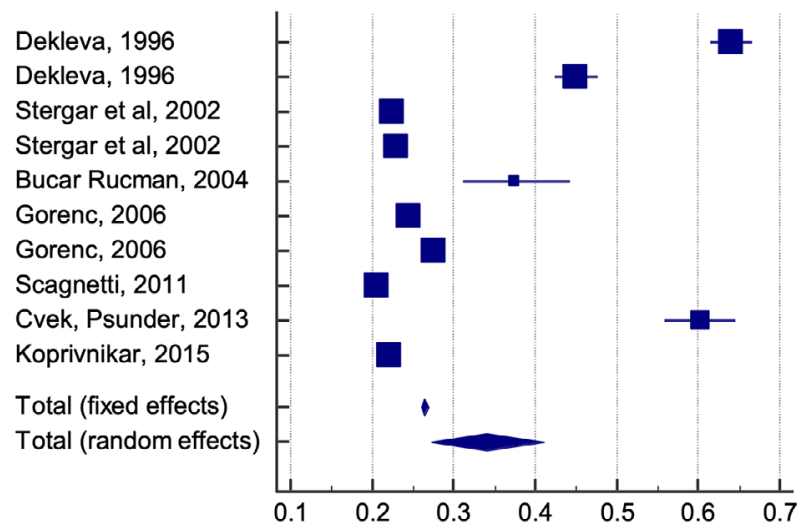

Graf I: Drevesni diagram z ocenami velikosti učinkov vseh vključenih raziskav (ločeno po vrsti vprašanj).

Simetričnost porazdelitve vrednosti učinkov vključenih raziskav smo preverili z izrisom lijakastega diagrama, ki je pokazal neenakomerno porazdelitev vrednosti in večja odstopanja. To potrjuje obstoj statistične heterogenosti, ki kaže na omejenost vključenih raziskav (Basu, 2017; Kastrin, 2008). To se zdi pričakovano že zaradi majhnega deleža raziskav z ustrezno navedenimi rezultati, ki smo jih lahko vključili v metaanalizo.

V nadaljevanju smo želeli preveriti, ali lahko heterogenost rezultatov pojasnimo z razlikami med podskupinami znotraj raziskav. $V$ ta namen smo analizirali razlike $\mathrm{v}$ deležih zaznavanja medvrstniškega nasilja glede na spol, vrsto vprašanj v raziskavi (viktimizacijska, samoprijavitvena ali o opažanju), leto raziskave in velikost vzorca. Zaradi nizkega števila podatkov, ki so nam na voljo, smo bili omejeni zgolj na te podskupine. Pridobljene izračune zaradi preglednosti združujemo v skupno Tabelo 3 .

Tabela 3: Rezultati primerjav med podskupinami, analiza na podlagi mešanega modela, s $95 \%$ intervalom zaupanja.

\begin{tabular}{|c|c|c|c|c|c|c|}
\hline \multirow[t]{2}{*}{ Podskupina } & \multirow{2}{*}{$\begin{array}{c}\text { št. } \\
\text { raziskav }\end{array}$} & \multirow[t]{2}{*}{$\begin{array}{c}\text { točkovna } \\
\text { ocena }\end{array}$} & \multirow[t]{2}{*}{ p-vrednost } & \multicolumn{3}{|c|}{ Heterogenost } \\
\hline & & & & Q-vrednost & $\mathrm{df}(\mathrm{Q})$ & p-vrednost \\
\hline & & & spol & & & \\
\hline moški & 6 & 0,317 & 0,000 & & & \\
\hline ženske & 6 & 0,243 & 0,000 & & & \\
\hline
\end{tabular}




\begin{tabular}{|c|c|c|c|c|c|c|}
\hline \multirow[t]{2}{*}{ Podskupina } & \multirow[t]{2}{*}{$\begin{array}{c}\text { št. } \\
\text { raziskav }\end{array}$} & \multirow[t]{2}{*}{$\begin{array}{c}\text { točkovna } \\
\text { ocena } \\
\end{array}$} & \multirow[t]{2}{*}{ p-vrednost } & \multicolumn{3}{|c|}{ Heterogenost } \\
\hline & & & & Q-vrednost & $\mathrm{df}(\mathrm{Q})$ & p-vrednost \\
\hline \multicolumn{7}{|c|}{ vrsta vprašanj } \\
\hline opažanje & I & 0,64 & 0,174 & & & \\
\hline samoprijava & 2 & 0,252 & 0,000 & & & \\
\hline \multirow[t]{2}{*}{ viktimizacija } & 7 & 0,318 & ০,০০০ & & & \\
\hline & IO & & & 10,946 & 2 & 0,004 \\
\hline \multicolumn{7}{|c|}{ leto raziskave } \\
\hline do 2000 & 4 & 0,373 & 0,091 & & & \\
\hline 2000 do 2010 & 4 & 0,27 & 0,001 & & & \\
\hline \multirow[t]{2}{*}{ od 2010} & 2 & 0,394 & 0,324 & & & \\
\hline & 10 & & & 1,629 & 2 & 0,443 \\
\hline \multicolumn{7}{|c|}{ velikost vzorca } \\
\hline do 1000 & 2 & 0,49 & 0,039 & & & \\
\hline $\begin{array}{l}\text { od } 1000 \text { do } \\
4000\end{array}$ & 4 & 0,373 & 0,915 & & & \\
\hline \multirow[t]{2}{*}{$\operatorname{nad}_{4000}$} & 4 & 0,236 & 0,000 & & & \\
\hline & IO & & & 7,385 & 2 & 0,025 \\
\hline
\end{tabular}

Iz izračunanih vrednosti, predstavljenih $\mathrm{v}$ Tabeli 4 , je razvidno, da spol $(\mathrm{p}=0,07)$ in leto raziskave $(\mathrm{p}=0,443)$ ne vplivata pomembno na pridobljene rezultate o deležu mladostnikov, ki so že imeli izkušnje $\mathrm{z}$ medvrstniškim nasiljem. Nasprotno je vrednost $\mathrm{p}$ manjša od 0,05 pri spremenljivkah »velikost vzorca $\ll(0,025)$ in »vrsta vprašanj《 $(0,004)$, vendar moramo biti pri interpretaciji previdni. Število vključenih rezultatov je namreč majhno, kar se kaže predvsem pri vrsti vprašanj. Zajeli smo namreč zgolj eno raziskavo, ki je spraševala po opažanju medvrstniškega nasilja nad tretjimi osebami (Dekleva, 1996). Ta v zgornjem prikazu (Tabela 2) že sama po sebi izstopa od porazdelitve vseh zajetih rezultatov z značilno višjo vrednostjo, zato je interpretacija takšne primerjave omejena. Ponovna analiza primerjave rezultatov po podskupinah brez te vrednosti pokaže, da ni statistično značilnih razlik med samoprijavitvenimi in viktimizacijskimi raziskavami $(\mathrm{p}=0,342)$. Podobno je treba upoštevati pri primerjavi po velikosti vzorca, saj raziskava Cvek in Pšunder (2013), ki v prikazu (Tabela 2) še najbolj odstopa, vpliva na visoko vrednost ocene zaznanega nasilja v skupini zgolj dveh raziskav z velikostjo vzorca do 1000. 
Tabela 4: Rezultati metaanalize vrednosti, ločenih glede na spol vprašancev.

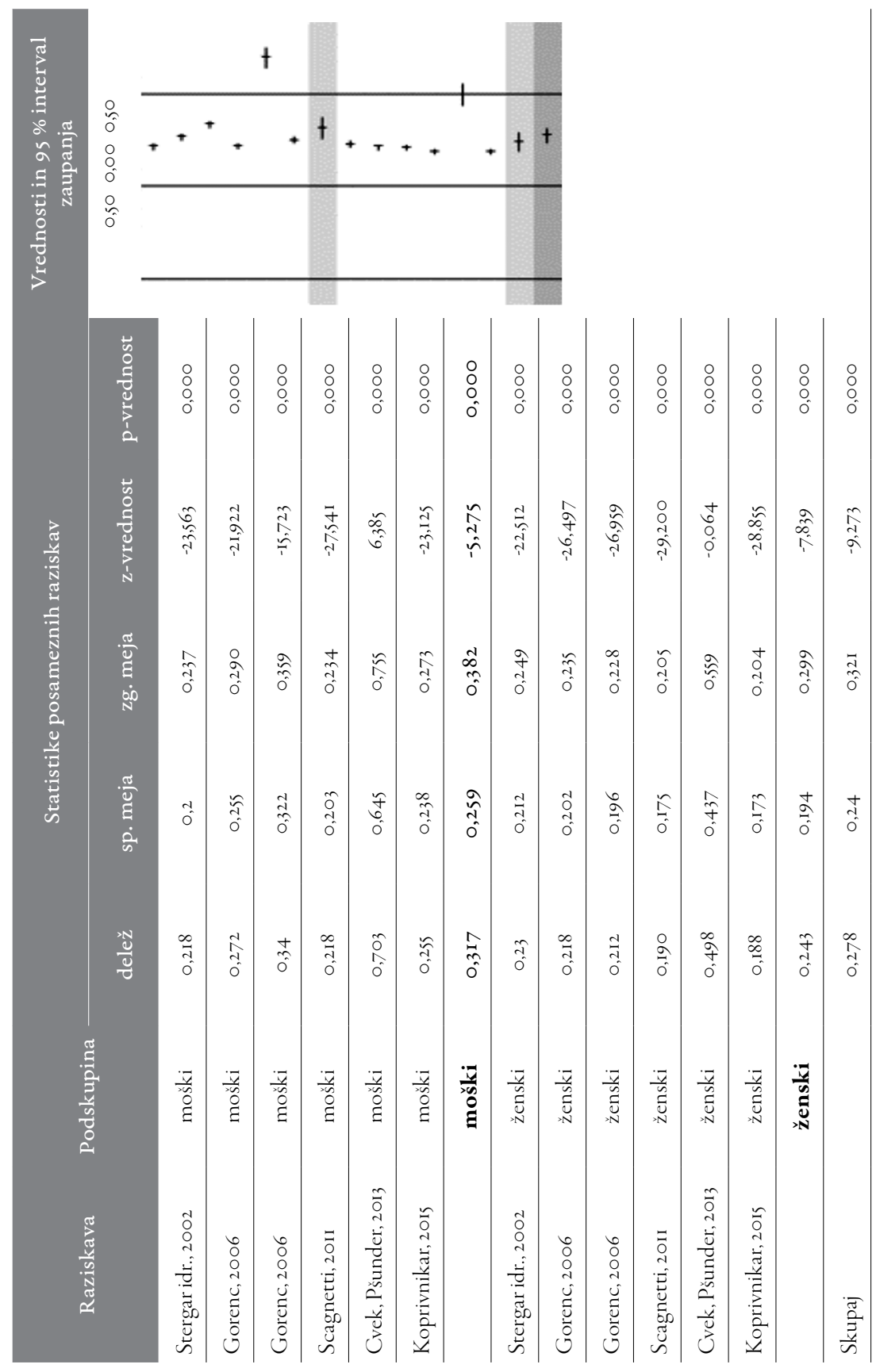


Delež zaznanega ponavljajočega medvrstniškega nadlegovanja (»vsaj občasno «)

Tabela 5: Rezultati metaanalize ponavljajočega se nadlegovanja za vse vrednosti raziskav glede na vrsto študije.

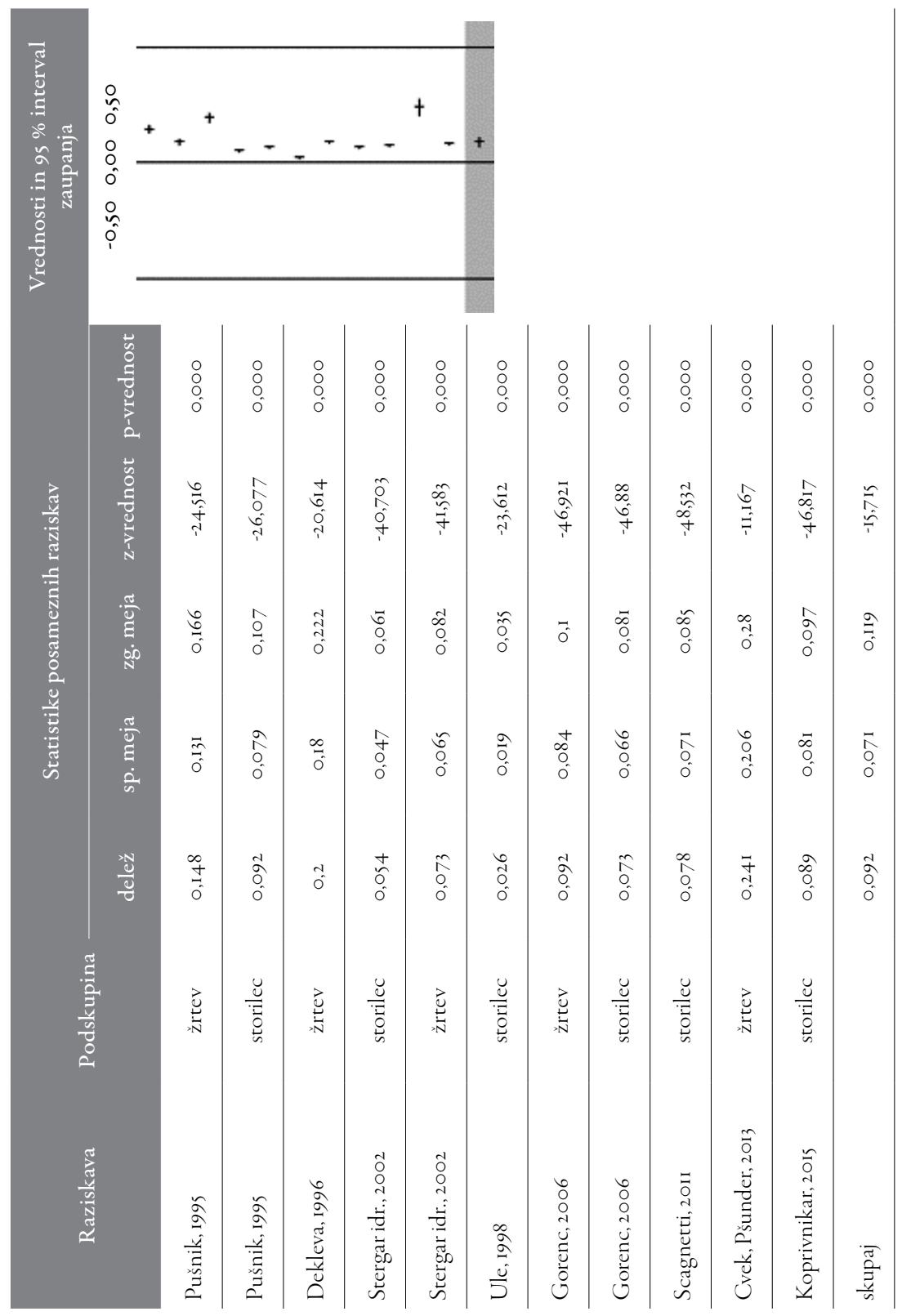




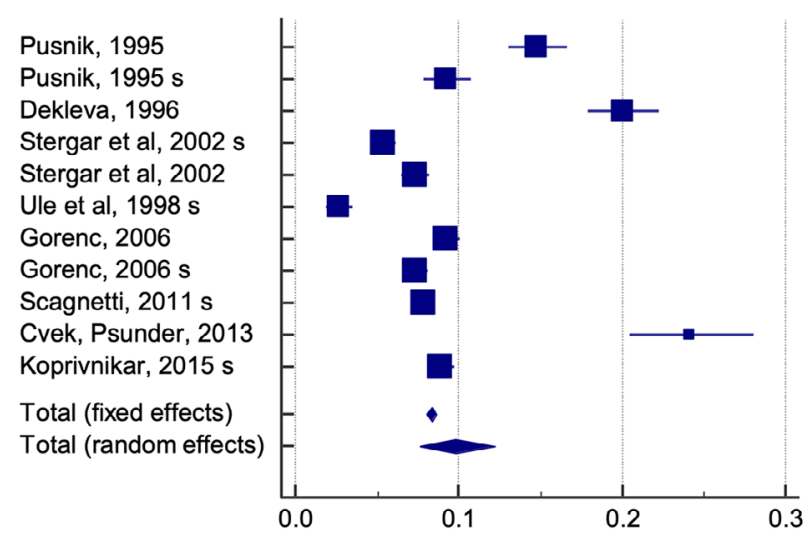

Graf 2: Drevesni diagram z ocenami velikosti učinkov vseh vključenih raziskav v analizo ponavljajočega se medvrstniškega nasilja (ločeno po vrsti vprašanj).

Odgovore na vprašanja, ki so spraševala po zaznavanju ponavljajočega se medvrstniškega nasilja (»vsaj občasno «, »vsaj kdaj pa kdaj《, »več kot enkrat do dvakrat « in podobno), smo analizirali z enakim pristopom, vendar ločeno, saj rezultati ponavljajočega se in enkratnega nasilja niso primerljivi. Raziskav z ustreznimi vrednostmi, ki smo jih lahko analizirali, je bilo v tem primeru sedem, različnih vrednosti pa Ir. Tudi pri analizi teh podatkov smo za metaanalizo uporabili model slučajnih učinkov. Rezultati so prikazani v Tabeli 5 .

Skupna ocena velikosti učinka znaša 9,2 \% (95 \% interval zaupanja: 7,I \% do II,9 \%) zaznanega ponavljajočega medvrstniškega nasilja. Izračun statistične heterogenosti $\left(\mathrm{I}^{2}=98,194 \%\right.$; $\left.=553,727, \mathrm{df}(\mathrm{Q})=\mathrm{IO}\right)$ pokaže, da je ta tudi v tem primeru visoka. Ponovno lahko zaključimo, da obstajajo vsebinske razlike med vključenimi raziskavami. V grafu lahko vidimo odstopanje istih dveh raziskav kot pri prvi analizi (Cvek in Pšunder, 2013, in Dekleva, 1996), kar postavlja pod vprašanje konsistentnost uporabljenih metodoloških pristopov. Statistično heterogenost smo ponovno preverjali z izrisom lijakastega diagrama, ki je pokazal podobna odstopanja kot v prejšnjem podpoglavju. 
Tabela 6: Rezultati primerjav deležev ponavljajočega se nasilja med podskupinami, analiza na podlagi mešanega modela, s 95 \% intervalom zaupanja.

\begin{tabular}{|c|c|c|c|c|c|c|}
\hline \multirow[t]{2}{*}{ Podskupina } & \multirow[t]{2}{*}{$\begin{array}{c}\text { št. } \\
\text { raziskav }\end{array}$} & \multirow[t]{2}{*}{$\begin{array}{c}\text { točkovna } \\
\text { ocena }\end{array}$} & \multirow[t]{2}{*}{$\begin{array}{c}\mathrm{p}- \\
\text { vrednost }\end{array}$} & \multicolumn{3}{|c|}{ Heterogenost } \\
\hline & & & & $\begin{array}{c}\text { Q- } \\
\text { vrednost }\end{array}$ & $\mathrm{df}(\mathrm{Q})$ & $\begin{array}{c}\mathrm{p}- \\
\text { vrednost }\end{array}$ \\
\hline \multicolumn{7}{|c|}{ spol } \\
\hline moški & 6 & 0,116 & 0,000 & & & \\
\hline \multirow[t]{2}{*}{ ženske } & 6 & 0,062 & 0,000 & & & \\
\hline & I2 & & & 7,104 & I & 0,008 \\
\hline \multicolumn{7}{|c|}{ vrsta vprašanj } \\
\hline samoprijava & 6 & 0,065 & 0,000 & & & \\
\hline \multirow[t]{2}{*}{ viktimizacija } & 5 & 0,138 & 0,000 & & & \\
\hline & II & & & 10,602 & I & ०,O०I \\
\hline \multicolumn{7}{|c|}{ leto raziskave } \\
\hline do 2000 & 6 & 0,083 & 0,000 & & & \\
\hline 2000 do 2010 & 3 & $0,08 \mathrm{I}$ & 0,000 & & & \\
\hline \multirow[t]{2}{*}{ od 2010} & 2 & 0,149 & 0,000 & & & \\
\hline & II & & & 2,493 & 2 & 0,287 \\
\hline \multicolumn{7}{|c|}{ velikost vzorca } \\
\hline do 1000 & I & $0,24 \mathrm{I}$ & 0,012 & & & \\
\hline $\begin{array}{l}\text { od I000 do } \\
4000\end{array}$ & 6 & 0,084 & 0,000 & & & \\
\hline \multirow[t]{2}{*}{ nad 4000} & 4 & 0,083 & 0,000 & & & \\
\hline & & & & 6,825 & 2 & 0,033 \\
\hline
\end{tabular}

Iz Tabele 6 je razvidno, da leto raziskave $(p=0,287)$ ne vpliva statistično pomembno na delež vprašanih z izkušnjami medvrstniškega nasilja. Nasprotno pa so razlike med podskupinami statistično značilne pri spolu ( $\mathrm{p}=0,0 \circ 8)$, z značilno višjimi vrednostmi izkušenj z nasiljem pri moških, vrsti vprašanj $(\mathrm{p}=\mathrm{o,0}, \mathrm{I})$, kjer več mladostnikov poroča o viktimizaciji kot o storilstvu, in velikosti vzorca $(\mathrm{p}=0,033)$. Raziskave $\mathrm{z}$ različno vrsto vprašanj so $\mathrm{v}$ tem primeru bolj enakomerno porazdeljene ( 6 samoprijavitvenih in 5 viktimizacijskih), nobena pa ni merila deleža opaženega medvrstniškega nasilja. Porazdelitev rezultatov je vidna v Tabeli 7, s statistično značilno nižjim deležem samoprijavitvenih odgovorov kot viktimizacijskih. 
Tabela 7: Rezultati metaanalize vrednosti ponavljajočega se nasilja, ločenih glede na vrsto vprašanj.

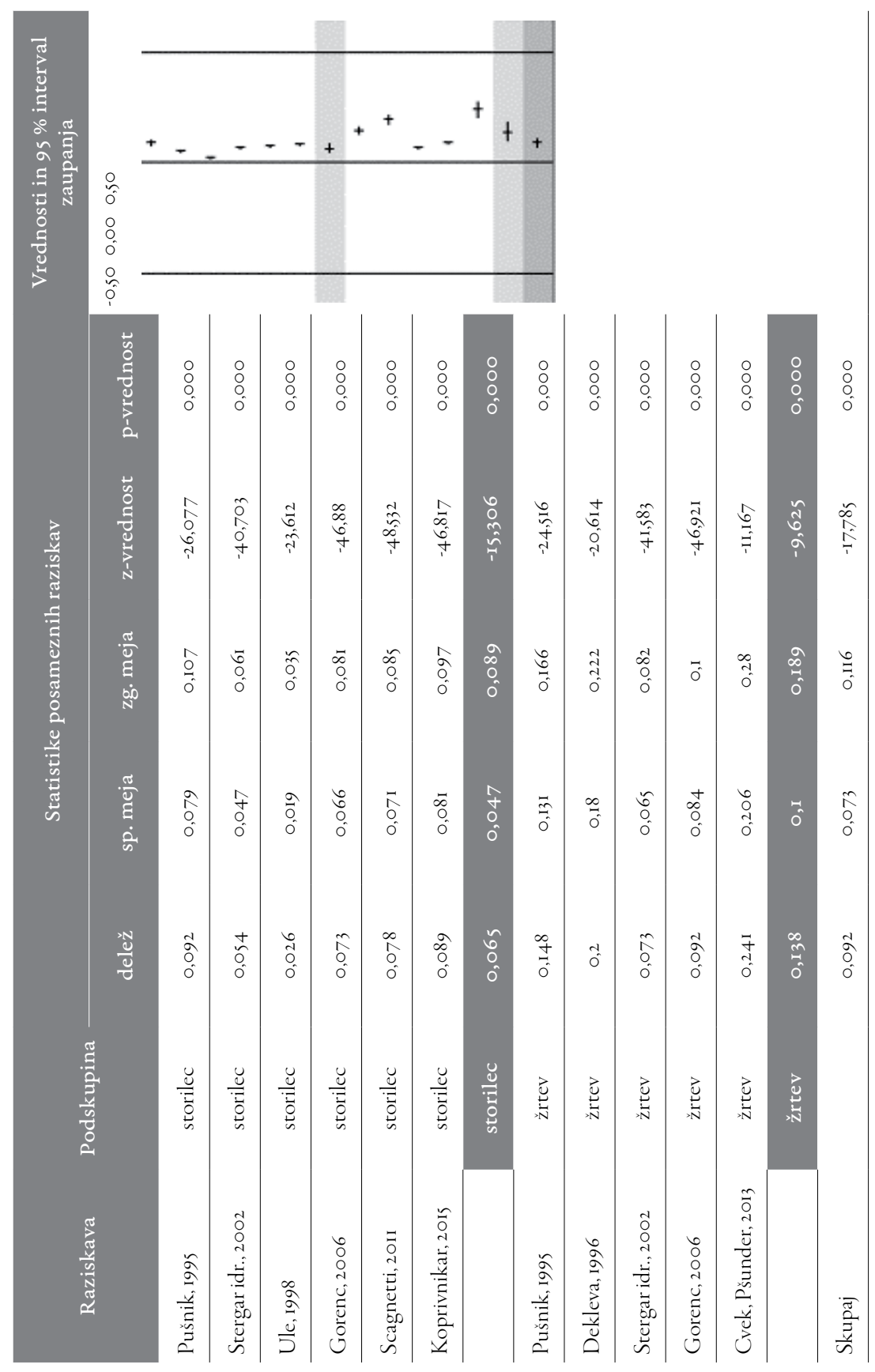


Tudi iz tega prikaza je razvidno odstopanje raziskav Cvek in Pšunder, 2013, in Dekleva, 1996. Ostale vrednosti so bolj enakomerno porazdeljene okoli točkovne ocene velikosti skupnega učinka (9,2\%). Ker obe omenjeni raziskavi merita zgolj viktimizacijo, je statistično značilno višja ocena velikosti učinkov le-te $(0,138)$ kot pri samoprijavitvenih vrednostih $(0,065)$ lahko posledica odstopanja teh dveh raziskav, zato imajo zaključki pomembne omejitve.

\section{Zaključna razprava}

Z opravljeno metaanalizo smo želeli podati oceno, kakšna je pojavnost medvrstniškega nasilja v Sloveniji, če upoštevamo rezultate vseh do sedaj opravljenih empiričnih raziskav na tem področju (1991-2019). S tem dobimo posplošene podatke, ki zmanjšujejo vpliv napak posameznih študij, hkrati pa lahko preverimo, katere lastnosti raziskovanja vplivajo na razlike $\mathrm{v}$ rezultatih. Zaključimo lahko, da je imelo na podlagi analiziranih prispevkov približno $33 \%$ otrok in mladostnikov že izkušnje z medvrstniškim nasiljem, 9,2 \% pa jih je odgovorilo, da so to zaznali večkrat. Analiza je pokazala, da se pojavnost skozi čas značilno ne spreminja, prav tako na odgovore ne vpliva pomembno, po kakšni vrsti izkušnje sprašujemo (storilstvu ali viktimizaciji), kadar raziskujemo enkratne izkušnje. Učenci in dijaki so občutno manjkrat odgovorili, da so takšno nasilje izvajali kot bili žrtve, kadar so avtorji poudarili, da sprašujejo o ponavljajočih se dejanjih. Pri teh so o izkušnjah tudi bolj pogosto poročali fantje kot dekleta. Po eni strani sicer to lahko pomeni, da gre pri ponavljajočem se nadlegovanju za specifična dejanja, ki jih pogosteje izkusijo fantje in jih izvaja manj otrok, kot jih je žrtev. To se zdi smiselno, saj je lahko nadlegovanje, ki ga izvaja en otrok, usmerjeno proti več žrtvam. Iz metodološkega vidika pa se na drugi strani poraja sum, da gre za večji vpliv družbene zaželenosti odgovorov, saj so ponavljajoča se dejanja hujša kot enkratna. Obstaja možnost, da to bolj upoštevajo deklice in zato težje priznajo vpletenost $v$ takšno dogajanje, hkrati pa - sploh, kadar gre za ravnanja z višjo stopnjo nezaželenosti otroci lažje priznajo, da so bili žrtev kot pa storilci.

Visoka stopnja izračunane statistične heterogenosti v analizi opozarja tudi na omejitve metaanalize. Že pri izboru raziskav v vzorec je bil naš kriterij lahko zgolj dostopnost in ustrezna oblika zapisa rezultatov, saj je primerljivih slovenskih raziskav občutno premalo, da bi jih lahko metodološko kategorizirali in selekcionirali. Hkrati je nekonsistentnost zapisa rezultatov med avtorji dodatno zmanjšala število raziskav, ki smo jih lahko vključili v metaanalizo, zato smo jih na koncu primerjali zgolj devet. Skupaj s pridobljenimi rezultati to kaže na neenotno raziskovanje, uporabo raznolikih metod in vzorcev ter, posledično, na omejitve pri 
primerjanju rezultatov. Del visoke heterogenosti namreč lahko pojasnimo z opaženo nekonsistentnostjo postavljenih vprašanj, opredelitve časovnega obdobja, za katerega nas izkušnje z medvrstniškim nasiljem zanimajo, opredelitev pogostosti izkušenj in podobno, kar se med raziskavami občutno razlikuje. Nadaljnje primerjave dodatno omejuje tudi dejstvo, da večina avtorjev $\mathrm{v}$ prispevkih ni natančno opisala uporabljene metodologije načina in vsebine vprašanj, časovnega obdobja, anketirancem niso podali definicij uporabljenih izrazov in podobno. Zaskrbljujoča je tudi (ne)raziskanost kibernetskega nasilja, kjer je primerjava zgolj štirih metodološko občutno raznolikih raziskav še posebej nesmiselna.

Zaradi obsežnega negativnega vpliva medvrstniškega nasilja je v interesu celotne skupnosti, da ga čim bolj omeji, sankcionira storilce, nudi pomoč žrtvam in vzpostavi čim bolj učinkovite preventivne programe. Ustreznega odziva na tako kompleksen pojav pa ni mogoče oblikovati brez poznavanja njegovih razsežnosti, oblik, pogostosti in okolja, kjer se dogaja, predispozicij storilstva in viktimizacije ter evalvacije uspešnosti obstoječih preventivnih programov oziroma ugotovitve, kje je pomanjkanje in česa obstoječi programi ne naslavljajo. Takšne podatke lahko pridobimo zgolj z raziskovanjem, vendar mora biti to kakovostno in zanesljivo, upoštevajoč specifičnost področja, ki izhaja iz raziskovanja z otroki, z žrtvami in storilci odklonskih ravnanj. Upoštevati je treba tudi to, da se izvajanje medvrstniškega nasilja prilagaja družbenemu in tehničnemu napredku ter se tako neprestano razvijajo nove oblike oziroma načini nadlegovanja in oškodovanja. Zaenkrat lahko podatke za Slovenijo črpamo zgolj iz posameznih parcialnih študij, ki so med seboj slabo primerljive, narejene v širokem časovnem razmahu, na vzorcih, ki ne odražajo nacionalnega nivoja, itd. Zaključimo lahko, da v Sloveniji nimamo poglobljenega vpogleda $v$ razmere na področju medvrstniškega nasilja. Nadaljnje raziskovanje bi se moralo usmeriti v izvedbo celostne, sistematične in longitudinalne študije medvrstniškega nasilja, ponovljene na določene časovne intervale. Ta bi morala osvetliti dogajanje med otroki in mladostniki. Vključiti bi bilo treba široko analizo odnosov med vrstniki, vključno z nasiljem, ki se ne izvaja zgolj na šolah, pač pa tudi drugje v vsakodnevnem življenju otrok.

\section{Literatura}

Althusser, L. (2000) Izbrani spisi. Ljubljana: Založba *Cf.

Basu, A. (2017) How to cunduct meta-analysis: a basic tutorial. PeerJ Preprints, 5. Dostopno na https://peerj.com/preprints/2978/ 
Boske, C. (2015) Bullied: What's Going on? V: C. Boske, in A. Osanloo (ur.), Students, Teachers, and Leaders addressing Bullying in Schools, str. I-22. Rotterdam: Sense Publishers.

Boske, C. in Osanloo, A. (2015) Uncomfortable Truths: An Introduction to Bullying in U.S. Schools. V: C. Boske in A. Osanloo (ur.), Students, Teachers, and Leaders addressing Bullying in Schools, xiii-I. Rotterdam: Sense Publishers.

Bovaird, J. A. (2010) Scales and Surveys: Some Problems with Measuring Bullying Behavior. V: S. R. Jimerson, S. M. Swearer in D. L. Espelage (ur.), Handbook of Bullying in Schools: An International Perspective, 275-292. New York: Routledge.

Bučar Ručman, A. (ur.) (2004) Nasilje in mladi. Novo mesto: Klub mladinski kulturni center.

Bučar Ručman, A. (2009) Kako se lahko učinkovito soočamo s šolskim nasiljem? V: V. Tašner, I. Lesar, M. Antić Gaber, V. Hlebec in M. Pušnik (ur.), Kako se labko učinkovito soočamo s šolskim nasiljem?, 363-377. Ljubljana: Pedagoška fakulteta.

Bučar Ručman, A. (2014) Migracije in kriminaliteta: Pogled čez meje stereotipov in predsodkov. Ljubljana: ZRC SAZU.

Craig, W. M. (1998) The Relationship Among bullying, Victimization, Depression, Anxiety, and Aggression in Elementary School Children. Pesonality and Individual Differences 24(I), str. I23-130.

Craig, W., Harel-Fisch, Y., Fogel-Grinvald, H., Dostaler, S., Hetland, J., Simons-Morton, B., Pickett, W. (2009) A Cross-national Profile of Bullying and Victimization Among Adolescents in 40 Countries. International Journal of Public Health 54(2), str. 216-224.

Cross, D., Lester, L. in Barnes, A. (2015) A Longitudinal Study of the Social and Emotional Predictors and Consequences of Cyber and Traditional Bullying Victimisation. International Journal of Public Health 60(2), str. 207-217.

Cvek, M. in Pšunder, M. (2013) Učenci, žrtve medvrstniškega nasilja. Revija za elementarno izobraževanje 6(4), str. 105-116.

Črešnik, M., Krope, S. F. in Lobnikar, B. (2005) Vrstniško nasilje v osnovnih šolah v Slovenj Gradcu. Varstvoslovje 7(3), str. 265-276.

Dekleva, B. (1996) Nasilje med vrstniki v zvezi s šolo - obseg pojava. Revija za kriminalistiko in kriminologijo 47(4), str. 355-365.

Dekleva, B. (1997) Vrstniško nasilje in ustrahovanje - značilnosti storilcev in žrtev. Revija za kriminalistiko in kriminologijo 48(4), str. 374-383. 
Dekleva, B. (200I) Semantika (med)vrstniškega nasilja. Revija za kriminalistiko in kriminologijo 52(I), str. 2I-3I.

Dekleva, B. (2002) Nasilje v življenju I5-letnih mladostnikov in mladostnic. V: B. Dekleva in Š. Razpotnik (ur.), Čefurji so bili rojeni tu, str. 91-I73. Ljubljana: Pedagoška fakulteta in Inštitut za kriminologijo pri Pravni fakulteti.

Filipčič, K., Bertok, E., Karajić, E., Klemenčič, I. in Muršič, M. (20I7) Nasilje v družini kot dejavnik medvrstniškega nasilja. Revija za kriminalistiko in kriminologijo 68(3), str. 218-234.

Gaffney, H., Ttofi, M. M. in Farrington, D. P. (2018) Evaluating the Effectiveness of School-Bullying Prevention Programs: An Updated Meta-analytical Review. Aggression and Violent behavior, accepted manuscript.

Gorenc, M. (2006) Nasilje med mladimi: Trpinčenje in pretepanje. V: H. Jeriček, D. Lavtar in T. Pokrajac (ur.), $Z$ zdravjem povezano vedenje $v$ šolskem obdobju: HBSC Slovenija 2006, str. I5I-160. Ljubljana: Inštitut za varovanje zdravja $R S$.

Graham, S. (2016) Victims of Bullying in Schools. Theory Into Practice 55(2), str. $136-144$.

Henry, S. (2000) What Is School Violence? An Integrated Definition. The Annals of the American Academy of Political and Social Science 567, str. I6-29.

Hunter, J. E. in Schmidt, F. L. (2004) Methods of Meta-analysis: Correacting Error and Bias in Research Findings. Thousand Oaks, CA: Sage.

Jontes, D., Luthar, B. in Oblak Črnič, T. (2015) Moč besed (raziskovalno poročilo). Dostopno prek http://www.telekom.si/ItakSi/Shared\%2o Documents/Raziskovalno_poro\%C4\%8Dilo_Moc_besed.pdf

Kastrin, A. (2008) Metaanaliza in njen pomen za psihološko metodologijo. Psihološka obzorja $17(3)$, str. 25-42.

Koprivnikar, H. (2015) Tvegana vedenja. V: H. Jeriček Klanšček, H. Bajt, A. Drev, H. Koprivnikar, T. Zupanič in V. Pucelj (ur.), $Z$ zdravjem povezana vedenja $v$ šolskem obdobju med mladostniki v Sloveniji: Izsledki mednarodne raziskave HBSC 20I4, str. 49-58. Ljubljana: Nacionalni inštitut za javno zdravje.

Kralj, A., Žakelj, T. in Rameša, M. (2013) Interethnic relations and peer violence in Austrian, Italian and Slovenian Schools. Annales: Series historia et sociologia 23(2), str. 259-260. 
Kramer, A., Kundija, M., Semič, E., Čuš, A., Velkavrh, T. in Pavlin, N. (2009) Raziskava o nasilju na slovenskih srednjih šolah. Ljubljana: Dijaška organizacija Slovenije.

Kramer, A., Mesarič, K. in Velkavrh, T. (2013) Raziskava o nasilju na slovenskih srednjih šolah II. Ljubljana: Dijaška organizacija Slovenije.

Lebar, L., Nagode, M. in Žerjav, N. (2017) Mladoletno prestopništvo in medvrstniško nasilje. V: A. Črnak Meglič in B. Kobal Tomc (ur.), Položaj otrokv Sloveniji danes: situacijska analiza, str. 247-263. Ljubljana: Inštitut RS za socialno varstvo.

Lešnik Mugnaioni, D., Koren, A., Logaj, V. in Brejc, M. (2009) Nasilje v šolah: opredelitev, prepoznavanje, preprečevanje in obvladovanje. Kranj: Šola za ravnatelje.

Lobe, B. in Muha, S. (2010) Tveganja in varnost otrok na internetu: Slovensko poročilo. Dostopno prek http://eprints.lse.ac.uk/46446/I/ SloveniaReportSlovenian.pdf

Lobe, B. in Muha, S. (20II) Internet v vsakdanjem življenju slovenskih otrok in mladostnikov: Prvo poročilo raziskave Mladi na netu. Ljubljana: Fakulteta za družbene vede.

Maljevac, S. in Magic, J. (2009) Pedri raus!: homofobično nasilje v šolah. Socialna pedagogika 4, str. 90-104.

Marjanovič Umek, L., Bahovec, I., Barle, A., Gačeša, M., Pavlovič, Z., Polajnar, B. in Vraber, S. (2004) Smernice za analizo, preprečevanje in obravnavo/obvladovanje nasilja $v$ šolskem prostoru. Ljubljana: Ministrstvo za šolstvo, znanost in šport. Pridobljeno na http://www. mizs.gov.si/fileadmin/mizs.gov.si/pageuploads/podrocje/razvoj_solstva/Smernice_nasilje.pdf

Moore, S. E., Norman, R. E., Suetani, S., Thomas, H. J., Sly, P. D. in Scott, J. G. (2017) Consequences of Bullying Victimization in Childhood and Adolescence: A Systematic Review and Meta-analysis. World Journal of Psychiatry $7(\mathrm{I})$, str. 60-76.

Netzley, P. D. (2014) How Serious a Problem Is: Cyber-bullying? San Diego, CA: ReferencePoint Press.

Olweus, D. (2009) Understanding and Researching Bullying: Some Critical Issues. V: S. R. Jimerson, S. M. Swearer in D. L. Espelage (ur.), Bullying in Schools: An International Perspective, str. 9-34. Cambridge: Cambridge University Press.

Parks, P. (2013) Cyberbullying. San Diego, CA: ReferencePoint Press.

Patchin, J. W. in Hinduja, S. (2008) Cyberbullying: An Update and Synthesis of the Research. V: J. W. Patchin in S. Hinduja (ur.), 
Cyberbullying Prevention and Response: Expert Perspectives, str. 13-35. New York: Routledge/Taylor \& Francis Group.

Posinc, K. in Košir, K. (2016) Medvrstniško nasilje, kot ga zaznavajo učitelji in učenci osnovne šole. Revija za elementarno izobraževanje 3, str. 5-22.

Pušnik, M. (1999) Vrstniško nasilje v šoli. Ljubljana: Zavod Republike Slovenije za šolstvo.

Pušnik, M. (20I2). Nasilje v šoli v krogu nasilja. V: M. Muršič (ur.), (O)krog nasilja $v$ družini in šoli: soočanje šole/vrtca $z$ nasiljem nad otroki, str. I07-I 44. Ljubljana: Inštitut za kriminologijo pri Pravni fakulteti.

Razpotnik, Š. (2006) Etnična samoopredelitev potomcev priseljencev, socialno ekonomski status in nasilje. Revija za kriminalistiko in kriminologijo $57(3)$, str. $240-247$.

Resolucija o nacionalnem programu preprečevanja in zatiranja kriminalitete za obdobje 2019-2023 (2019). Ljubljana: Vlada Republike Slovenije.

Riebel, J., Jager, R. S. in Fischer, U. C. (2009) Cyberbullying in Germany An Exploration of Prevalence, Overlapping With Real Life Bullying and Coping Strategies. Psychology Science Quaterly 5I(3), str. 298-3I4.

Rodseth, R. in Marais, L. C. (2016) Meta-analysis: Everything You Wanted to Know But Were Afraid to Ask. SA Orthopaedic Journal, I5(4). Dostopno na http://www.scielo.org.za/scielo. php?script $=$ sci_arttext\&pid $=$ SI68I-I50X 2016000400005

Scagnetti, N. (20II) Pretepanje in trpinčenje. V: H. Jeriček Klanšček, S. Roškar, H. Koprivnikar, V. Pucelj, M. Bajt in T. Zupanič (ur.), Neenakosti $v$ dravju in $z$ zdravjem povezanih vedenjih slovenskih mladostnikov, str. 248-26I. Ljubljana: Inštitut za varovanje zdravja v Sloveniji.

Smith, P. K. (2016) Bullying: Definition, Types, Causes, Consequences and Intervention. Social and Personality Psychology Compass io(9), str. 519-532.

Stergar, E., Scagnetti, N. in Pucelj, V. (2002) Trpinčenje (bullying) in pretepanje. V: E. Stergar, N. Scagnetti in V. Pucelj (ur.), $Z$ zdravjem povezano vedenje v šolskem obdobju: HBSC Slovenija 2002, str. 79-87. Ljubljana: Inštitut za varovanje zdravja RS.

Sullivan, K. (2011) The Anti-Bullying Handbook. London: Sage.

Thornberg, R. (2011) ,She's Weird!' - The Social Construction of Bullying in School: A Review of Qualitative Research. Children \& Society 25, str. $258-267$. 
Ttofi, M. M. in Farrington, D. P. (2009) What works in preventing bullying: effective elements of anti-bullying programmes. Journal of Agression, Conflict and Peace Research I(I), str. 13-24.

Twyman, K. A., Saylor, C. F., Saia, D., Macias, M. M., Taylor, L. A. in Spratt, E. (2010) Bullying and ostracism experiences in children with special health care needs. Journal of Developmental Behavioural Paediatrics 3I(I), str. I-8.

Ule, M. (1998) Mladina 'g8: Socialna ranljivost mladih. Dostopno prek https://www.adp.fdv.uni-lj.si/opisi/mla98/

Weber, N. L. in Pelfrey, W. V. jr. (2014) Cyberbullying: Causes, Consequences, and Coping Strategies. El Paso, TX: LFB Scholarly.

Završnik, A. (2013) Kibernetsko nadlegovanje: Pojem, metode in pojavnost po svetu in v Sloveniji. V: M. Ambrož, K. Filipčič in A. Završnik (ur.), Zbornik za Alenko Šelih: kazensko pravo, kriminologija, človekove pravice, str. 427-448. Ljubljana: Pravna fakulteta.

Završnik, A. in Sedej, A. (2012) Spletno in mobilno nadlegovanje v

Sloveniji. Revija za kriminalistiko in kriminologijo 63(4), str. 263-280.

DOI: https://www.doi.org/10.32320/1581-6044.30(I-2)63-88 